\title{
Innovation in Music
}

Performance, Production, Technology and Business

\section{Edited by Russ Hepworth-Sawyer, Jay Hodgson, Justin Paterson and Rob Toulson}

First published 2019

31

The End of a Golden Era of British Music?

Exploration of Educational Gaps in the Current UK Creative Industry Strategy

Carola Boehm

(CC BY-NC-ND 4.0) 


\title{
The End of a Golden Era of British Music?
}

\author{
Exploration of Educational Gaps in the \\ Current UK Creative Industry Strategy
}

\section{Carola Boehm}

\section{INTRODUCTION}

The creative industries, and particularly our UK Music industry, are perceived as healthy, resilient and strong. However, with the ongoing policy changes in secondary and higher education, as well as the continued cuts to council budgets and the ongoing lack of commitment to wealth distribution and even investment in the whole nation, this golden era of the creative industries in the UK may not last. In my latest articles, I explore critical themes relevant for the UK Music industry and the UK creative sector as a whole. Current national policy expressions often omit to address these themes, which are necessary to safeguard our future creative resilience. In writing this article, much relevance will be drawn from making connections to recent public debates on what universities are for and what their role is within the creative economy. Attention is given to considering current governmental industry strategies critically and their relevance for the music industry, together with their sector responses.

\section{AREN'T WE DOING WELL IN THE MUSIC INDUSTRY?}

Over the last two decades, the music industry, and more generally the creative and cultural industry as a whole, has had a successful period of growth and expansion (UK Music, 2017b; Creative Industries Council, 2017). It has in recent times been heralded as one of the few sectors in growth while the productivity of the rest of the economy seems to have stalled; thus, the music and creative industries are outgrowing the UK economy. UK Music has pointed out that there are still areas that need to be addressed to ensure continued growth in the future, specifically relating to the increase of digital cultures and its related issues of fair remuneration to artists and rights' holders as music consumption changes from physical ownership to streaming (UK Music, 2017b). Relevant to these themes, Brexit and its effect on the creative sector has also given rise to new anxieties about the ability to continue our golden area of creativity within the UK political trajectories (CIF, 2017). 
With the sector's success as the fastest growing part of the UK economy, consecutive governments have been increasingly afforded to consider it explicitly in their economic strategies. The political agendas have moved from realizing the potential of the creative industries back in 2001 (DCMS, 2001), to policy imperatives in 2008 (DCMS, 2008), to industrial strategy (BIS, 2017), which is currently influenced and informed by both an independent review of the creative industries (Bazalgette, 2017) and the Arts Council's commissioned report on the value of the creative economy (CEBR, 2017). Back in 2001 the Government's vision was of "a Britain in ten years' time, where the local economies in our biggest cities are driven by creativity", and this was-I suggested in a series of articles - to be a major shift in the perception of the value of arts and creativity (Boehm, 2009, 2014, 2015b, 2016b; Patterson and Boehm, 2001).

However, although the creative industries are perceived as healthy, resilient and strong (ACE, 2017a), recent policy expressions and their interventions often neglect vital aspects (or barriers) that are likely to hamper future productivity growth within the creative industries, including the music industry. These themes include:

- connectivity of place, people, cultures (including open-innovation partnership models)

- continued policy emphasis for our learning organizations on knowledge content (and learning outcomes) rather than on educational environments for developing creative life-long learners within a knowledge economy context

- $\quad$ significance of Culture 3.0 concepts with its possible future of a vanishing creative industry as a demarcated sector, as user/producer divides disappear and co-production models take over

This article will focus more on the first two themes, the first section covering creative sector strategies in relation to national infrastructures, such as how to cope with the north-south economic divide, its effects on our creative economy. The second theme focuses on recent policy interventions both at secondary and tertiary educational levels and their direct impact on development of creative talent. The third theme, Culture 3.0, although relevant for the subject matter of this chapter, has been developed in depth in some recent articles (Boehm, 2016a; Sacco, 2014), but in short is based on a new type of cultural engagement where the need for large intermediaries, such as labels, diminishes and consumer/producer divides vanish with technologically immersive and immediate environments.

\section{FRAGMENTATION AND DISCONNECTEDNESS: CONNECTIVITY OF PLACE, PEOPLE AND CULTURES}

The creative and cultural economy is highly fragmented (characterized by a high proportion of what the media associates with the gig economy) and is populated by a large number of 'one-man bands', e.g. micro-cultural producers, including sole traders and self-employed. The "gig economy", 
or more positively framed as "new forms of more flexible working", is becoming a characteristic work practice in an increasing number of fields, including music and the creative industries. This was the topic of a short conference in London, on June 13, 2017, where it was suggested that

the number of self-employed workers in Britain has grown by 1 million between 2008 and 2015 (Office for National Statistics, 2016), while so-called zero-hours contracts have also reached a record high. This "uber-ification" of the workplace signals a transformation in labor relations and structures of employment that raises pressing questions about the future of work.

(CAMRI, 2017)

This mirrors the music sector, where "the vast majority of music businesses are small or micro companies, and the music industry has a higher proportion of sole traders and freelance workers than the average sector" (UK Music, 2012). The UK Music report goes on to highlight that their income is often not from one single source, and unless VAT registered and employing workers using PAYE, they may not appear on business registers. By 2017, the UK Music report does not mention sole traders or self-employed, but just denotes measures related to individual types of professions as part of its rigorous definition of what the music industries are (UK Music, 2017a). Thus, in its 2017 report, the largest contribution (2bn GBP of a total of 4.4bn GBP) for the total GVA in 2016 was that of musicians, composers and songwriters.

This fragmentation provides a high amount of sector resilience, even in times of economic upheaval, as the aftermath of the 2008 financial crisis and subsequent recession has demonstrated. However, this high fragmentation also carries with it a disproportionate risk and vulnerability to the smallest denominators. Micro-cultural producers and the small end of the Small and Medium Enterprises (SMEs) are highly vulnerable on an individual basis, and a lack of sufficient wealth distribution on a national basis affects the productivity of this sector. So, where statistics are available, they demonstrate that creative producers in today's world are less likely to survive solely from their earnings. Thus, a 2017 report for literature suggested that in 2005 approximately $40 \%$ of authors survived solely from the earnings they made through their writing, and this was reduced to $11.6 \%$ eight years later in 2013 (ACE, 2017c).

Additionally, where the middle classes are squeezed, productivity based on SMEs - where the critical mass of start-ups and small businesses are initiated - is affected, and this creates also a geographical disconnect, or as we experience in the UK, a substantial north-south economic divide.

The north-south productivity/wealth divide has given rise to devolution arguments, and were recognized as being significantly influential in the 2015 general election outcomes. Paul Mason's Channel 4 blog presented an interesting map for the time around the general election of 2015.

The digitally aged paper map, still available at the open democracy website on Hanson's Blog (www.opendemocracy.net/uk/steve-hanson/ 
northern-powerhouse-as-real-mirage), overlays the UK cleverly onto the Finnish geographies, with Scotland being "Southern Scandinavia" taking up the rural, most northern part of Finland on the map; Greater London is depicted as part of the "asset-rich southlands", geographically overlaying areas that would theoretically include Helsinki and Turku; and the Finnish Archipelago being labeled as the "Post-Industrial Archipelago", which, as Hanson suggests, represents

the Detroitified, abandoned middle, drawn as spiky red islands. Like the "new" north-south split, there is nothing new about this map either. It has just gone public for the first time, as it suddenly matches voting swings more closely than it did before.

(Hanson, 2015)

A more fact-based graph can be seen in Booner's report for HEFCE on University-Industry Collaboration (Bonner et al., 2015), where most of the graphs indicate that economically London is doing very well, and the rest of the country is not. This picture is reiterated in various metricsproductivity, income, employment and when considering the music industry, a similar picture emerges with most of the SME indies being located in the London area.

Some might consider this to be the "natural order of things", but the central focus of assets and resources, as well as governance, is far from being inevitable, and the UK is the most centralized government of the G7. The success in other European countries is often based on much wider, devolved and distributed governance (compare Germany), investment and wealth distribution models.

In the UK, this resulted in a long-standing lack of commitment to investments in infrastructures that provide connectivity throughout the nation, and not just to the London metropole. The theme of the underconnected northern powerhouse has been subject to increasing expression for a stronger commitment to building more devolved high-speed railways, e.g. HS3 before HS2 or amending HS2 to include HS3 elements. It would thus connect the northern part of the UK before building yet another improvement to London's connectivity (Wand, 2017; Shaw, 2017; RTM Rail Technology Magazine, 2017; IPPR North, 2012, 2017). Improving the connectivity of the musical powerhouses of Liverpool, Manchester and Leeds would help not only to close the creative productivity gap between the north and the south but also to unleash a further productivity potential held by this creative nation, which is held back by the bottlenecks (and the high cost of living) that London represents in a centric nation. Specifically, for the music and creative industry, regional infrastructure could be considered as vital. However, the lack of commitment to addressing the geographical disconnects are continually evident, such as in November 2017, when Transport Minister Grayling announced that plans were being accelerated to reopen the railway line from Oxford to Cambridge, ahead of any other transport infrastructure plan in the North (Topham, 2017). 
There is also the perceived disconnect between the cultural creative forprofit and not-for-profit sector, which is having a big effect on the creative industries in a geographically biased manner. Where there is insufficient continued investment in the cultural sector, specifically considering that the creative industries are much closer to the not-for-profit third sectors and cultural not commercially driven actors, there tends to be a lack of SME resilience. Thus, both the former and current CEOs of the Arts Council (Bazalgette and Henley) have spoken out on this matter of regional cultural deficits outside of London. Bazalgette put the blame of regional cultural deficits firmly on consecutive council cuts (Thorpe, 2014), and Henley reiterated the London versus the regions issue as one of the most pressing arts policy debates in England, and with his taking up the CEO mantle promised "more of a two-way street" (Hanley in Brown, 2015). When Darren Henley joined the Arts Council in 2015, he put in place initiatives that will ensure that $75 \%$ of $\mathrm{ACE}$ funding goes to regions outside London by 2018, and a map of the newly funded portfolio organizations, published in 2017, demonstrated the implemented commitment to attain these targets (ACE, 2017b).

In a similar vein, and considering university-industry collaborations, the 2015 HEFCE report (Bonner et al., 2015) indicated that whereas the average SME Creative Industries sector lies at around $8.7 \%$, London has a share of $18.8 \%$ of Creative Industries SMEs. Some of the areas with the lowest employment figures demonstrate a below-average level of enterprise and creative industries, e.g. Stoke-on-Trent is highlighted (p. 15) as the area with the lowest share of SME Creative Industries. Stoke-onTrent is an interesting example here, as with its pitch in 2017 for becoming City of Culture 2021 it has recontextualized itself as the ceramic city (besides being Soul-on-Trent, the "home of northern soul", with a long tradition of supporting a flourishing music club scene) that has both a long-standing industrial heritage based on a creative industry sector and a flourishing future creative cluster. But as the crafts sector, and with it, the whole micro-producing ceramics sector, was left out of NESTA's 2016 Geography of Creativity (Mateos-Garcia and Bakshi, 2016), because craft business "does not lend itself easily to the approach used in the report" as "evidence shows that $88 \%$ of craft businesses are sole traders". So NESTA and the Crafts Council can clearly learn something from the UK Music and the Music sector, which have managed to devise a methodology to continually try to ensure that micro-cultural producers and their value to the economy are counted. This is increasingly becoming more important, as governments base their policy decisions on these commissioned reports, with (perhaps) an over-reliance on their contained metrics.

Thus, for instance, when the initial call for the $£ 45$ million Creative Industries Clusters Programme was launched by the AHRC as part of its Industrial Strategy Challenge fund, it originally emphasized the use of NESTA data to ensure that only pre-existing clusters mentioned in NESTA would be eligible. Thus, as an example of the challenge of high fragmentation and its measurability, Stoke-on-Trent-one of the oldest and deepest creative clusters, albeit predominantly made up of micros and SMEs - did 
not feature in NESTA's report on the creative industries (Mateos-Garcia and Bakshi, 2016). On the other hand, Crewe and Cheshire East were mentioned, but they appeared due to the high spill-out of the publishing industry from Manchester into the Macclesfield region. These are typical pitfalls of sectors that have a very high fragmentation, which make it difficult to get a sense of what is going on. I laud again the transparent and rigorous methodology published by UK Music (UK Music, 2017a), which can potentially set a standard for other highly fragmented sectors when attempting to measure their economic value, and provide visibility and effective advocacy.

It is also worthwhile mentioning that with the demise of free access to higher education, another pressure on what Germans call the "Mittelstand" (closest equivalent is the concept of SMEs) has been mentioned-the need for the middle class to increasingly absorb student debt, which hampers enterprise start-up, productivity and/or growth (Newfield, 2016). Student debt, of course, leads to the next point - educational environments.

\section{THE RISE OF STANDARDIZATION}

Perhaps resulting from the dissolution of the UK government's department of Business, Innovation and Skills during the overhaul of Whitehall in July 2016 by new prime minister Theresa May, with Higher Education (HE), Further Education (FE) and apprenticeship joining the government Department of Education, a new conceptual distance between innovation and education allowed a second major theme to be not sufficiently addressed by the governmental industrial strategy: that of arts education in secondary and tertiary education. Higher Education was brought together within a department encultured in standardization and regulation, and this had an immediate impact on the HE sector. As Ken Robinson put it even more bluntly: "If you run an education system based on standardization and conformity that suppresses individuality, imagination and creativity, don't be surprised if that's what it does" (Robinson and Aronica, 2015).

As the UK Music advocacy group argued: "future talent will never get the chance to shine if we continue to see cuts in music in schools and closures in venues where artists need to learn their craft in the first place" (UK Music, 2017b). But the governmental strategy from November 2017 still seems to rely on the need for technical education above anything else. It suggests, "We will also update school and college performance measures to ensure that students can make an informed choice between technical or academic education in time for the introduction of the first T levels, recognizing them as equally valued routes" (BIS, 2017, p. 102).

In relation to arts provision, Bazalgette pointed out in his independent review that "industry should develop . . . curriculum materials to broaden and deepen the talent pipeline that starts at school" (Bazalgette, 2017, p. 10), as if schools have not been involved in creative education for the last decade, despite increasing numbers of interventions by government to cut arts provision for the sake of STEM, and this despite all evidence of its effectiveness to the contrary. So rather than introducing industry 
intervention into the school sector (after decades-long governmental interventions and affordability of university-school interventions), it might be useful to consider other national school models that seem to support learner excellence, as measured by PISA metrics (Programme for International Student Assessment). It is hard not to mention the Finnish model of school education (Sahlberg, 2017) in this context, which has not only allowed school performance to be steadily improved over the last 20 years but has produced this with a high amount of equity and well-being, and less standardization or competition.

On the opposite scale, in the UK, we are just average performers in PISA metrics, and the mental health and well-being of both school and university based learners is critically low; the productivity levels in our economy are the worst they have been for a long time. On top of this, student debt is at an all-time high and social mobility at an all-time low. Simultaneously, head teachers up and down the country are expressing their dismay at having to close or to stop more creative subject provision, such as music, drama and art, within their schools (Ratcliffe, 2017; Savage, 2018).

The result of the recent decades of standardization, competition and corporatization (and the following quote seems to fairly accurately describe both secondary and tertiary education systems) includes

alarming rates of non-graduation from school and colleges, the levels of stress and depression - even suicide - among students and their teachers, the falling value of a university degree, the rocketing costs of getting one, and the rising levels of unemployment among graduates and non-graduates alike.

(Robinson and Aronica, 2015)

We need to do something different in our educational systems. Rather than another governmental intervention into curriculum, or new teacher/ staff/institutional performance metrics, what is needed is a complete rethink at local/regional levels with associated freedoms to implement what learners need in our knowledge economy. The focus here, as many have argued, should be on learning environments, rather than a focus on knowledge content. The basic question that needs to be asked here, both at secondary and tertiary levels, is if we live in a knowledge economy with knowledge being all around us, what is the role of schools and universities and how should they support the development of learners to confidently navigate, critically reflect, creatively produce and significantly contribute to our society's future?

In a 2010 keynote speech at the Royal Society of Arts (Robinson, 2010), Robinson gave a short summary of our still current school challenges:

Every country on the earth is at the moment reforming education. There are two reasons for this. The first of them is economic. They are trying to find out how do we educate children to take their place in the economies of the 21 st century-how do we do that-given that we can't anticipate what the economy will look like at the end of 
next week - as the recent turmoil has demonstrated. How do we do that? ... The second is cultural: Every country on the earth is trying to figure out how we educate our children so they have a sense of cultural identity, how do we pass on the genes of our culture, while being part of globalization. How do we square that circle.

(Robinson, 2010)

As mentioned in 2016 (in Boehm), Robinson suggests that our learning organizations still prioritize a very particular way of academic thinking that excludes many children and young people. The existing system, he argues (Robinson and Aronica, 2015), is still based on an outmoded industrial revolution model, based on standardization and essentially the principles of factory production. It is still an "industrial character of public education" and thus is deeply flawed.

This industrial heritage created an ingrained believe in standardization, based on the need to provide a mass public schooling system. This "modernistic model of prioritizing highly specialized knowledge causes problems for the divide between the practice-based (or vocational, but the different terms have different connotations) and the academic" (Boehm, 2014). This is evident in secondary education, and the presence of the divide continues right into tertiary education. As Robinson suggests, the concept of dividing the vocational from the academic is based on a series of assumptions about social structure and capacity and a very specific intellectual model of the mind.

[This] was essentially the enlightenment view of intelligence. That real intelligence consists of this capacity of a certain type of deductive reasoning and a knowledge of the classics, originally. What we came to think of as academic ability. And this is deep in the gene pool of public education, that there are two types of people, academic and non-academic. Smart people and non-smart people. And the consequence of that is that many brilliant people think they are not, because they are being judged against this particular view of the mind.

(Robinson, 2010)

Robinson goes on to suggest that this has caused some of the perceived misery in our school education systems:

The problem is that they're trying to meet the future by doing what they did in the past. And on the way they are alienating millions of kids, who don't see any purpose of going to school. When we went to school, we were kept there with a story, which if you worked hard and did well, and got a college degree you would have a job. Our kids don't believe that. And they are right not to-by the way. You're better having a degree than not, but it is not a guarantee anymore. And particularly not if the route to it marginalizes everything you think is important about yourself.

(Robinson, 2010) 
Thus, our (secondary) educational institutions have been increasingly afforded to standardize the curriculum, standardize teaching and standardize assessment. And the biggest threats from the recent political climates within a neo-liberal encultured political norm are the strategies taken by successful government to attain standards: by standardization, by introducing competition, and by allowing corporatization.

The typical reform story goes like this: A high-performing education system is critical to national economic prosperity and to staying ahead of our competitors. Standards of academic achievement must be as high as possible, and schools must give priority to subjects and methods of teaching that promote these standards. Given the growth of the knowledge economy, it's essential that as many people as possible go on to higher education, especially four-year colleges and universities.

Because these matters are too important to be left to the discretion of schools, government needs to take control of education by setting standards, specifying the content of the curriculum, testing students systematically to check that standards are being met, and making education more efficient through increased accountability and competition.

(Robinson and Aronica, 2015)

And when standards are not improving, the unfailing belief that the system is inherently the right one leads to greater efforts in raising standards through introducing even more competition and even more accountability. This standards movement is allegedly making systems more efficient and accountable, but the result is that we have one of the lowest productivity levels in decades, low innovative entrepreneurial output in international terms, and a mental health crisis linked to the stresses of constant performance measurement.

Most countries now have a national curriculum of some form, often specifying year-level knowledge content. This is true for England, France, Germany, China and many others. Somewhat looser frameworks exist in Scotland, and notably Finland (Sahlberg, 2017) and, so far, the US and Singapore. Pasi Sahlberg has written extensively on the success of the Finnish education model, which he suggests is based on being a "cultural outlier" (Sahlberg, 2017, p. xxi). Finland had school policies that were almost the opposite of those introduced in the Anglo-American sectors and much of the rest of the world. Thus, it could be seen as a story of the impact of alternative education solutions, those based on a core belief in cultivating trust, enhancing autonomy and supporting diversity. Key drivers for this success are suggested to be found in the greater amount of local school and teacher autonomy, and the lack of census-based standardized testing, test preparation and private tutoring. "In Finland, teachers teach less and students spend less time studying both in and out of school, than their peers in other countries" (Sahlberg, 2017, p. 14).

In Sahlberg's view, standardizations stand in opposition to creativity. In educational systems where standardization is perceived to be the key, there 
is often the suggestion that what is needed to attain standards are introductions of competition, test-based accountability, but with a resulting perception of de-professionalization, and (as he suggests) an addiction to reform, together with a belief in the notion of "excellence". Alternatively, systems that tend to do better are ones that allow creative flexibility of content and personalized learning, including aspects of collaboration, and a belief that this is based on trust-based responsibility, along with experiential professional leadership and a firm belief in equity, all resulting in a sustained improvement.

This belief in equity is, of course, something that does not come easy to us in an England still entrenched in class cultural divides. Even less accepted is the consideration that the prioritization of equity is essential for economic and social well-being, and that there should be the same provision of access to education for everyone. In his post-Brexit-vote article, Dutchman Luyendijk suggested that the Brexit vote was a "logical outcome of a set of English pathologies" (Luyendijk, 2017), and that "a nation that gave the world the term "fair play' sees the fact that rich children receive a better education than poor ones as a perfectly natural thing". Luyendijk's article is a very painful read for those who do not believe that money should give you the right to access better education, and whereas this belief has simply been put aside in the Finnish system with a comprehensive buy-in into equity for all, Britain's ruling majorities - and more specifically England's - sees this as a fair, neo-liberal, market-driven and competitively more productive system in the long run-despite all evidence to the contrary.

But with this belief, creativity and our UK passion for music-making is in danger of being squeezed out, despite all indicators pointing toward the need to include more creative practice in everyday school environments. Standardization has also made this more difficult:

It is clear to me that one of the main obstacles in focusing more on real learning, giving more room to music and arts in American schools, building learning in schools around curiosity, creativity and exploration of interesting issues, is standardized testing.

(Sahlberg, 2017)

Sahlberg goes on to hammer the US systems using an increasing amount of standardization, to suggest that "perhaps most importantly, I don't know any other OECD country where cheating and corruption are so common in all levels of the school system than it is in the U.S., only because of the dominance of standardized tests".

Until quite recently, universities were out of the spotlight from successive governments, but have now become the newest scapegoat of choice, as David Sweeney suggested at a 2017 SRHE conference keynote. Over the last 18 months, various government officials seemed to have washed their hands of the responsibility for the mess in which our nation finds itself, as George Monbiot has stated in his recent journalistic explorations of class, inequality, environment, growth obsessions and financial 
crises (Monbiot, 2016). Universities have been asked by politicians to take responsibility for (a) growing economic productivity, (b) increasing social mobility, (c) solving the challenge of our failing school systems, (d) meeting the increasing expectations of student consumers, (e) reducing immigration and (f) doing all that with minimal public funding and simultaneously being increasingly forced to allow market forces to regulate their work.

The view currently often portrayed by ministers and therefore the media is that universities are a separate entity, still an ivory-tower-like structure. But what the government does not seem to understand is that universities are as much a part of society as all our communities are. The same state structures that allow the growing gap between the richest and the poorest in society is driving a similar gap between the smallest salary earners and the richest within academia. The government's newest university scapegoat is Vice-Chancellors' salaries, and although the debate between the richest and the poorest is a valuable debate to be had in terms of debating social inequalities, to focus on universities here is a confusing message: on the one hand, the government introduced market competition in the HE sector, deregulation and freedom to innovate, but then on the other hand, they simultaneously ask for the highest amount of scrutiny, public accountability and comparison with the public sector - and this to a degree that few private sectors experience (Rushforth, 2017). English universities are thus being torn asunder - on the one hand asked to act as businesses while on the other having to undergo intense public-accountability processes. This constantly feels like being knotted tightly into a publicaccountability straightjacket, with hands and feet tied behind your back, while being thrown into a competitive free-market shark tank. The only movement left is squirming, and that is certainly what the HE sector is doing at the moment.

Subsequent policy interventions resulted in our HE sector being less diverse than ever before, as every institution is afforded to hunt after the same performance indicators that the government continues to throw down at its feet, from REF, to NSS, to DLHE, to TEF to now the upcoming KEF (or written out: Research Excellence Framework, National Student Survey, Destination of Leavers in Higher Education Survey, Teaching Excellence Framework and Knowledge Exchange Framework). This is also standardization, but here in $\mathrm{HE}$ it is driven predominantly by standardization of key performance indicators representing what the government perceives to be teaching quality, graduate outcomes, research excellence and knowledge exchange metrics. This has created a risk-averse, neo-liberal, overly managerial-reliant system that is inefficient in its excessive need to justify every part of its process.

There is a Wiley Miller political cartoon from 2012 that still holds true today. A row boat contains eight managers at a table with graphs and metrics informing the single rower of his performance metrics and telling him how to row faster. Productivity just does not work when the focus is more on getting the performance correctly measured in order to instruct the dwindling group of front-line employees. But the government 
interventions have increasingly made it necessary for the number of professionals involved in accountability, scrutiny, quality assurance, data analysis and justification of resources to be steadily increased. With the coming into force of the Higher Education and Research Act 2017, and the introduction of a sector regulator, the increasing focus on value for money is about to become even more complicated (CDBU, 2017).

For students, English universities represent not only the most expensive higher education system in the world, but also a system with one of the highest administrative costs. This is undoubtedly primarily a result of governmental interventions (see also Boehm, 2016a). Thus, universities are increasingly forced to compete with each other in a climate where the need to make an institution more nationally competitive within its own $\mathrm{HE} \mathrm{sec-}$ tor, also through league table positioning, takes priority over the socioeconomic benefit to a region. England is only one of a few countries where the stance of commercially conceptualized HE has been implemented to such an extreme: a "university market" selling education as a consumer good.

Now private providers do not necessarily represent a bad thing, and the music sector is one of the only creative industry sectors with flourishing private for-profit and private not-for-profit new HE entrants. Students have flourished and successfully made their careers based on degrees from BIMM, FutureWorks, ICMP, SAE and others, with each provider able to contribute specific strengths to the market. However, there is a different role that these providers have within society compared to universities that are still - according to the industrial strategy-anchors in their region and supporting economic growth and society as whole, by having a multi-purpose holistic remit with a civic mission. The fact that things will undoubtedly go wrong more often with private for-profit providers with their inherent larger potential of conflicts of interest has been outlined in detail in The Great University Gamble: Money, Markets and the Future of Higher Education by Andrew McGettigan (McGettigan, 2013).

For McGettigan the issue of marketization of Higher Education is also about democratic deficits, and these can be found not only in the way that a country is governed (with our First-Past-The-Post non-proportional electoral system) but also in the way university departments choose to appoint their Heads or Deans (elected vs. permanent managers). This movement from flat-structured networked knowledge organizations to the belief that universities need strong, central decision-makers also focused employees on those leaders to whom they are accountable to, rather than to look to the surrounding society (Wright and Shore, 2017, p. 78). This intentional increase of these democratic deficits has led to a path toward what Newfield calls the "The Great Mistake: how we wrecked public universities and how we can fix them" (Newfield, 2016) and is a follow-up to his "Unmaking of the Public University" (Newfield, 2008). In the US, a system often seen to be further advanced in the marketization narrative, this has led to locked-in economic inequality and systemic lack of student attainment while society must cope with student debt.

For me personally, there are glimmers of hope that we, as a society, and we, as a sector, are starting to be more assertive in our arguments that the 
English HE solution may not necessarily be the way to design the future. Yes, we live in a different world than just ten years ago, our knowledge society and our knowledge economy has arrived, and this does mean that knowledge institutions have to consider how this affects them. New models of educational frameworks are needed. Over the past two years, I have had the privilege to be involved with entrepreneurial creative communities that are planning either not-for-profit but private music higher education provision or cooperatively owned university provision. An increasing number of professionals and academics are considering alternative futures for higher education and with it the role of universities in the future. Old and new universities are increasingly beginning to (re-) emphasize their civic mission, and there have been increasing calls for revisiting the concept of what universities are for, what a public university should be and the reiteration of the need for societally engaged universities with an institutional and individual conscience that break the ivory tower concepts once and for all (Levin and Greenwood, 2016; Collini, 2012; Watson, 2014). The implications of universities as anchors with a focus on the knowledge economy is explored in Perry and May's Cities and the Knowledge Economy: Promise, Politics and Possibilities (May and Perry, 2017), and the threats of not having a public university system is explored in a recent volume, Death of the Public University? (Wright and Shore, 2017). Pedagogical underpinnings are revisited and newly proposed, from students as producers (Neary and Winn, 2009; Neary, 2010), to a focus on learning environments moving away from outcome-based learning (Thomas and Brown, 2011; Davidson, 2017), to research-embedded learning as part of a cohesive discovery-based learning framework (Fung, 2017).

There are new initiatives to explore the viability of the first UK cooperative universities (Bothwell, 2016; Cook, 2013; Winn, 2015). "New old" models of HE are being explored, focusing back on private vs. common vs. public good, including alternative models such as trust universities (Boden et al., 2012; Wright et al., 2011; Wright and Shore, 2017), and also, more relevant for the creative sector, my own expressions of the role of universities in the creative economy and society (Boehm, 2015b, 2014, 2015a, 2016a, 2016b; Boehm et al., 2014).

A healthy debate has emerged, and just in the two months of November and December 2017, there were four conferences mixing policymakers, educators and researching academics, all concerned with focusing on the role of universities in contemporary society. On the November 6-7, WONKHE's Wonkfest17 took place, with the fabulous strapline "Revenge of the Experts". On November 9, there was the Coop College's inaugural "Making the Co-operative University: New Places, Spaces and Models for Learning". The same week saw the Centre for Higher Education Futures (CHEF)'s inaugural international conference "The Purpose of Future Universities" in Aarhus. And in December, SRHE's annual conference in Newport had the strapline: "Higher Education Rising to the Challenge: Balancing Expectations of Students, Society and Stakeholders". 


\section{CONCLUSION}

In conclusion, I do see a glimmer of hope in the increasing articulations of alternatives to the neo-liberal conceptualized models of (unsustainable) sustainability. These articulations go far beyond the music industry, in which this publication's readership is contextualized, but they have particular relevance to it. And as music is one of the oldest creative practicebased disciplines in the academy and in schools, its communities are at the forefront of considering what it means to be involved in education, research and development for a creative society.

We know that if we do not attend to our secondary and tertiary education infrastructures and fail to include music and creative provision in our curricula, we will not have a creative future in which music-making in all its forms can flourish. We might find ourselves looking back and realizing that in the last 25 years in Britain, we had lived in a golden age of music, culture and the arts, having fostered a whole generation of artists who had led the way within a global cultural community, driving our very own diversity-rich, international, but also very uniquely British creativity, in music and the arts. If we don't ensure that music and arts feature as elements within our learning institutions, this will be an era whose end has just started with the 2017 general elections, Brexit and the subsequent educational reforms, with their ongoing focus on standardization squeezing out any notion of creative freedom for young talent.

Universities play a large role here, but the climate in which British $\mathrm{HE}$ finds itself has its own challenges. So, before we even start connecting the dots of the challenges described here, we need to understand the context that universities find themselves in and the challenges that this context provides in devising effective learning provision. This will justify the needed move from formalized and structured learning objects to formalized structured learning environments, and this journey has only just begun. There are examples where this has always happened in practice, specifically in music and the arts. These examples provide lessons to be learned for those universities who truly want to be connected. Music and creativity have a large part to play here, especially because "culture is not simply a large and important sector of the economy, it is a 'social software' that is badly needed to manage the complexity of contemporary societies and economies in all of its manifold implications" (Sacco, 2014).

\section{REFERENCES}

ACE (2017a). Creative sector is taking a leading role in boosting the UK economy | press release. London: Arts Council England.

ACE (2017b). Interactive map: Our funded organisations, 2018-2022 | report (Arts Council England).

ACE (2017c). Literature in the 21st century: Understanding models of support for literary fiction | report (Arts Council England. Commissioned report by Canelo). Arts Council. 
Bazalgette, P. (2017). Independent review of the creative industries-GOV.UK.

BIS (2017). Industrial strategy: Building a Britain fit for the future-GOV.UK. In: Department for business energy \& industrial strategy. London: BIS.

Boden, R., Ciancanelli, P. and Wright, S. (2012). Trust universities? Governance for post-capitalist futures. Journal of Co-operative Studies, 45, pp. 16-24(9).

Boehm, C. (2009). 2084-brave creative world: Creativity in the computer music curriculum. In: Proceedings of the international computer music conference. Montreal, ICMA.

Boehm, C. (2014). A brittle discipline: Music technology and third culture thinking. In: E. Himoinoides and A. King, eds., Researching music, education, technology: Critical insights. Proceedings of the Sempre MET2014. London: University of London.

Boehm, C. (2015a). Engaged universities, mode 3 knowledge production and the impact agendas of the REF. In: S. Radford, ed., The next steps for the research excellence framework. London: Westminster Forum Projects.

Boehm, C. (2015b). Triple helix partnerships for the music sector: Music industry, academia and the public. In: R. Hepworth-Sawyer, ed., International conference on innovation in music 2015. Cambridge: KES Transactions.

Boehm, C. (2016a). Academia in culture 3.0: A crime story of death and birth (but also of curation, innovation and sector mash-ups). REPERTÓRIO: Teatro \& Dança, 19, pp. 37-48.

Boehm, C. (2016b). Music industry, academia and the public. In: International computer music conference. Ghent, International Computer Music Association.

Boehm, C., Linden, J. and Gibson, J. (2014). Sustainability, impact, identity and the university arts centre. A panel discussion. In: ELIA, ed., Location aesthetics. 13th ELIA biennal conference. Glasgow, European League of Institutes of Arts.

Bonner, Karen \& Hewitt-Dundas, Nola \& Roper, Stephen. (2015). Collaboration between SMEs and universities - local population, growth and innovation metrics. 10.13140/RG.2.1.4145.9365.

Bothwell, E. (2016). Plan to "recreate public higher education" in cooperative university. Times Higher Education. London, THE.

Brown, M. (2015). Arts council England to increase ratio of funding outside London.@guardian.

Camri (2017). Creative Industries and beyond: is the "gig economy" the way forward? Policy Observatory of the Communication and Media Research Institute (CAMRI). Conference Announcement for 13 June. London: University of Westminster.

CDBU (2017). Value for money are students right to complain? London: Council for the Defense of British Universities.

CEBR (2017). Contribution of the arts and culture industry to the UK economy | (Arts Council commissioned report).

CIF (2017). Global talent report (Creative Industries Federation).

Collini, S. (2012). What are universities for? London and New York: Penguin.

Cook, D. (2013). Realising the co-operative university. A consultancy report for The Co-operative College. 
Creative Industries Council (2017). News: Creative industries add $\$ 87.4 b n$ to UK economy.

Davidson, C. N. (2017). The new education: How to revolutionize the university to prepare students for a world in flux. New York: Basic Books.

DCMS (2001). Creative industries mapping document. London: Department for Culture Media and Sports.

DCMS (2008). Creative Britain: New talents for the new economy. London: Department for Culture Media and Sports.

Fung, D. (2017). A connected curriculum for higher education. London: UCL Press.

Hanson, S. (2015). The Northern powerhouse as "Real Mirage": The new maps of Britain, and how we should understand them. I openDemocracy. @ opendemocracy.

IPPR North (2012). Northern rail priorities statement: five priorities for immediate action and investment.@IPPR.

Ippr North (2017). New transport figures reveal London gets $£ 1,500$ per head more than the North-but North West powerhouse "catching-up”. @IPPR.

Levin, M. and Greenwood, D. J. (2016). Creating a new public university and reviving democracy: Action research in higher education. New York: Berghahn Books.

Luyendijk, J. (2017). How I learnt to loathe England. @prospect_uk.

Mateos-Garcia, J. and Bakshi, H. (2016). The geography of creativity in the UK. London: Nesta.

May, T. A. and Perry, B. A. (2017). Cities and the knowledge economy: Promises, politics and possibilities. London: Routledge.

McGettigan, A. (2013). The great university gamble: Money, markets and the future of higher education. London: Pluto Press.

Monbiot, G. (2016). How did we get into this mess? Politics, equality, nature. London and Brooklyn, NY: Verso.

Neary, M. (2010). Student as producer: Research engaged teaching and learning at the University of Lincoln user's guide 2010-11. Lincoln: University of Lincoln.

Neary, M. and Winn, J. (2009). The student as producer: Reinventing the student experience in higher education. In: L. Bell, H. Stevenson and M. Neary, eds., The future of higher education: Policy, pedagogy and the student experience. London: Continuum.

Newfield, C. (2008). Unmaking the public university: The forty-year assault on the middle class. Cambridge, MA: Harvard University Press.

Newfield, C. (2016). The great mistake: How we wrecked public universities and how we can fix them. Baltimore: Johns Hopkins University Press.

Patterson, J. and Boehm, C. (2001). Circus for beginners. In: G. Boehm and Schuter, eds., CIRCUS 2001-new synergies in digital creativity. Proceedings of the conference for content integrated research in creative user systems. Glasgow: University of Glasgow.

Ratcliffe, R. (2017). Cuts, cuts, cuts. Headteachers tell fo school system "that could implode”.@guardian.

Robinson, K. (2010). Changing education paradigms. In: Annual conference for the royal society for arts. London: Royal Society for Arts. 
Robinson, K. and Aronica, L. (2015). Creative schools: The grassroots revolution that's transforming education. New York: Viking.

Rtm Rail Technology Magazine (2017). Majority rules: We must build HS3 first. @rtmnews.

Rushforth, J. (2017). VCs' salaries-go compare and justify-association of heads of university administration. John Rushforth, Executive Secretary of the Committee of University Chairs (CUC), gives his personal views on the debate around Vice-Chancellors' pay and benefits and discusses the justification of salaries of HE senior leaders.

Sacco, P. L. (2014). Culture 3.0. ELIA Keynote Talk, European League of Institutes of the Arts, Glasgow.

Sahlberg, P. (2017). Finnish lessons 2.0: What can the world learn from educational change in Finland? New York: Teacher's College Press.

Savage, M. (2018). Top musicians unite in call for all pupils to have the right to learn an instrument.@guardian.

Shaw, J. A. (2017). Building HS3 before HS2 - should happen. Retrieved from: https://www.constructionnews.co.uk/markets/sectors/infrastructure/buildhs3-before-hs2-major-think-tank-says/10009614.article.

Thomas, D. and Brown, J. S. (2011). A new culture of learning: Cultivating the imagination for a world of constant change. CreateSpace Independent Publishing Platform.

Thorpe, V. (2014). Peter Bazalgette on regional arts funding: "blame lies with council cuts”.@guardian.

Topham, G. (2017). Rail services lost under1960s beeching cuts may reopen. @ guardian.

UK Music (2012). The economic contrubution of the core UK music industry. UK Music.

UK Music (2017a). Measuring music 2017-methodology.

UK Music (2017b). Measuring music 2017-UK music.

Wand, M. (2017). The case for building an HS3 before HS2. Retrieved from: https://shouldhappen.com/building-hs3-before-hs2/

Watson, D. (2014). The question of conscience: Higher education and personal responsibility. London: Institute of Education Press.

Winn, J. (2015). The co-operative university: Labour, property and pedagogy. Power and Education, 7, pp. 39-55.

Wright, S., Greenwood, D. and Boden, R. (2011). Report on a field visit to Mondragón university: A cooperative experience/experiment. Learning and Teaching: The International Journal of Higher Education in the Social Sciences (LATISS), 4, pp. 38-56.

Wright, S. E. and Shore, C. E. (2017). Death of the public university? Uncertain futures for higher education in the knowledge economy. Oxford: Berghahn Press.

\section{FURTHER READING}

Bazalgette, P. (2017). Independent review of the creative industries-GOV.UK. BIS (2017). Industrial strategy: Building a Britain fit for the future-GOV. UK. London: Department for Business Energy \& Industrial Strategy.

(One of the current key reports covering recommendations for the creative industries) 
Boehm, C. (2014). A brittle discipline: Music technology and third culture thinking. In: E. Himoinoides and A. King, eds., Researching music, education, technology: Critical insights. Proceedings of the Sempre MET2014. London: University of London.

(An article covering the challenges of interdiscplinarity in Higher Education in the area of music technology)

Boehm, C. (2015). Triple helix partnerships for the music sector: Music industry, academia and the public. In: R. Hepworth-Sawyer, ed., International conference on innovation in music 2015. Cambridge: KES Transactions.

(An article covering a new partnership model paradigm, its evolution and challenges for the future)

Boehm, C. (2016). Academia in culture 3.0: A crime story of death and birth (but also of Curation, Innovation and Sector Mash-ups). Repertório: Teatro \& Dança, 19, pp. 37-48. CIF (2017) Global Talent Report (Creative Industries Federation).

(An article covering in details the concept of Culture 3.0 and its relevance for the creative and cultural sector)

Robinson, K. and Aronica, L. (2015). Creative schools: The grassroots revolution that's transforming education. New York: Viking. SDG (2017) Exploring the role of arts and culture in the creative industries-Exploring the role of arts and culture in the creative industries.

(An extended treatment on the benefits of keeping creative subjects in school and the evolution of educational policy that made this increasingly difficult).

\section{NOTES ON CONTRIBUTOR}

Carola Boehm is Associate Dean (Students) and Professor of Arts and Higher Education in the School of Creative Arts and Engineering at Staffordshire University. Her research areas include music technology education, interdisciplinarity in Higher Education and the role played by universities in the creative economy. 